Nonka Bogomilova

Professor, Dr.Sc.

Bulgarian Academy of Sciences

nonka_bogomilova@mail.bg

https://doi.org/10.18485/rit.2021.19.35.1
UDK: $2-1$

141.4

316.74:2

Originalni naučni rad

Datum prijema: 12.03 .2021

\title{
RELIGION WITHIN FRAMEWORK OF PHILOSOPHICAL AND SOCIOLOGICAL APPROACHES
}

\begin{abstract}
Summary
The paper presents an overview on some specificities of philosophical and of sociological approaches to religion. Among the chosen philosophical epistemological models are described: religion as universum (F.Schleiermacher, G.W.F.Hegel); the anthropocentric approach; the religion interpreted as a moral phenomenon (I.Kant); religion within the framework of dichotomies of human nature (E.Fromm, P.Tillich). The author presents and comments a few aspects of the J.Beckford's analysis of problems and trends in the sociology of religion. The latest development in the Cognitive science of religion (CSR) are emphasized.
\end{abstract}

Keywords: knowledge of religion, philosophy of religion, sociology of religion, problems and theories, epistemological models, Cognitive science of religion.

\section{Religion today as targeted by various and alternative interpretations}

In modern theoretical perspectives, particularly in the philosophy of religion and sociology of religion, that define the epistemological and methodological horizons of religious studies, the debates on the essence of religion are continuing - debates that started as far back as the time of the Enlightenment.

What is religion? The innovative and respecting tradition contemporary answer of this question is not only of theoretical and abstract meaning. It would help solving important concrete social, political, legal problems: regarding the identification of the religious organizations; the criteria for registration as religious community; the reason for granting specific rights; the differentiation between religious and quasi-religious groups; questions of non-traditional, alternative religions, questions regarding the "return of magic", the role of religion for constructing religious identities, for the legitimization of the state, its connection with violence and with social cohesion.

Many contemporary authors outline alternative interpretations of the role and place of religion in late modernity: 1) according to one interpretation, a pro- 
cess of revitalization of religion is going on, of desecularization, which includes new forms and manifestations of religiousness; thus we find that religion is undergoing yet another "kairos" (in Paul Tillich's sense of the term) in its history, i.e. a supreme moment in time for it;2) alternatively, secularization is considered to be a continuing process, and religion, though mutating into new forms, has long since lost the social "ontological primacy" that it had in past historical periods, a primacy that has now gone to the state.

Concretely, for example not only the institutional, but also the discoursive and existential dimensions of European identity (Sazonova 2018) are becoming more secularized.

The theoretical clarification of above issues needs clarifications of the very notion of religion, given by philosophical and sociological approaches. The philosophy of religion faces the complex task of dealing adequately with the internal logic, internal truth of religion, while transcending individual, empirically given religions in order to provide knowledge of their common essence (Greish 2004; Gabellieri 2004). Philosophy makes sense of religion in the following thematic and problem areas: in the context of the human universe, it focuses on ritual, practices, institutionalized tradition; it deals with religion with reference to the religious transcendent subject as interpreted in metaphysics, hermeneutics, and anthropology; in the perspective of absolute principles, one of which is the defense of religious pluralism. According to Greish there are five models of philosophy of religion: the speculative (Hegel), the critical (Kant, Tillich, Troeltsch, Feuerbach, Nietzsche, etc.), the phenomenological (Scheler, Eliade), the linguistic (Frege, Wittgenstein, Evans, etc.), and the hermeneutic (Ricoeur) (Raynova, 1997: 26).

The theoretical perspective on the concept of "human essence", when directed at the concept of religion, mediates and surmounts the sharp disciplinary and confessional divisions and distinctions in the definition of religion, providing instead a matrix that transcends them, but is methodologically "hospitable" for them. Seen in the universalistic perspective, the concept of religion makes no claim to be a substitute for, nor to deprive of individuality, the cultural-historical specific features and study of separate religions; it does not offer the alternative of a meta-religion, but rather provides flexible methodological and normative reference points, which can be applied according to the value system and theoretical paradigm underlying the research approach of each thinker.

Regarding some of the classical philosophic and religious-philosophic models of interpreting religion, if we approached them not in the perspective of their 
disciplinary distinctions and conceptual oppositions, but as "human facts", as attempts at understanding and assessing the essential nature of religion in the perspective of the essence of man manifested in and through religion, then the concept of "religion" would reveal its rich, many-layered content. A philosophical-culturological review of the crucial points in this process of "building" the concept, i.e. its cultural-historical and historical-philosophical context, conceptual and psychological determinations, distinguishes several epistemological models (Bogomilova 2010).

\section{Religion as universum (F. Schleiermacher, G.W.F. Hegel)}

The first of the models is related to an extremely broad understanding of religion as a specific sort of spiritual universe. This is most strongly presented by F. Schleiermacher (1768-1834), but is also characteristic of the conceptions of G. W. F. Hegel $(1770-1831)$ and P. Tillich. This view is also evident to some degree in E. Fromm's idea of religion, but in a limited and reduced form, not with reference to the human essence in its entirety, but only to one of the two kinds of human experience (the so-called x-experience). For both Hegel and Schleiermacher the elements of the world, of the universe, are mutually linked and mutually manifest: the internal and external, beyond and within, subjective and objective, man, God and nature. All these realities and notions, which are mutually opposed in other philosophical systems, are here interwoven together and form a harmonious whole: "you yourself are a brief compendium of humankind, your person encompasses in a certain sense the whole of human nature, and the latter is, in all its depictions, only your own Self multiplied, more clearly delineated, and perpetuated in all its transformations." (Schleiermacher 1994: 47). Thus Schleiermacher describes the way in which the universe is given in religious contemplation. Similarly to this, for Hegel, "Religion itself consists in the occupation of feelings and thought with the absolute essence ... self-forgetting of one's specificity in this rising and acting in this sense, with a view to the absolute essence." (Hegel 2004: 104). Moreover, in this "self-forgetting", man himself transforms into a superior being: "Spirituality as well as the natural will, the empirical, immediate spirit, man - comes to know himself through religion in his essence, comes to know that the basic definition is not to be dependent on nature but to know himself free, as a mind" (Hegel 2005: 161). The synthesis of the two principles is also indicated: "The subject of religion is the true, the unity of subjective and objective."(Hegel 1996: 136). 
But whereas for Schleiermacher the "sense" with which man observes the free play of Spirit that unites all principles, is feeling, contemplation, reverence, for Hegel it is reason, cognition. That is why the higher synthesis in Hegel's system is between being and the notion, a synthesis achieved through philosophical knowledge. In it is reconciled the "hostility" between essence and existence, between objective and subjective, man and God, the essence of religion and its specific forms.

Even though the "sense" through which religion is made manifest and is practiced is different for the two philosophers, they come significantly close to each other in their general view regarding the "place of man in the universe", regarding the relationship between the human essence and the essence of the absolute, regarding religion as a relationship between these essences. Of course, in Schleiermacher's case this is a matter of emotion, of joyful play, of reverence in religious contemplation, while in Hegel's, we have the colossal and exhausting work of philosophical reason needed to produce, as a result of philosophical reflection, this living, vibrant whole, which, for emotional contemplation, is something immediately given.

The analyses of the two philosophers concern the essence, the "mythological" or "fantasized" interpretation of man and religion, and the relation between this interpretation and the actual man and actual religions is dramatic, ridden with contradictions. While in the early Hegel the relation was highly critical and even negative, in his later works the existing religions become "moments of religion in general", and Hegel seeks to discover the commensurability of the historically concrete being of human nature and the respective historically defined religion, ultimately establishing the apogee of the movement through history in the "true idea of religion", in the full combination of the human and divine in the Christianity practiced in his homeland.

Schleiermacher was exceptionally critical of the religion and Church of his own time, and he saw the only alternative to them as residing in his own deeply internal view of religion as the work of "religious virtuosos" who must bring the Church over to such an intimate view.

The connecting of the essential nature of religion with human nature relates religion to the basic and positive definitions of man: reason, freedom, the feeling of participation in the absolute and in the harmonious universe; the procedure recalls the common, essential, which lies behind the cultural-historical differentiation of religions. 


\section{The anthropocentric approach: Ludwig Feuerbach (1804 - 1872).}

A different epistemological model is presented in the conception of Ludwig Feuerbach. Here man is placed at the centre, becomes a reference point and value criterion in his relations with nature, society, and God. Man is interpreted as an integral being, endowed with reason, feelings, passions, vitality, and none of these determinations should be over-stressed or underestimated. Human essence is indeed represented in the divine essence, but since man is not just one part among others of the general order of the universe, but is rather the centre of that order, this representation of man in God is alienation, which should be criticized and abolished. The mutual relation, the mutual response between principles, which we see in Hegel and Schleiermacher, is here done away with, for man assumes the whole of value, feeling and reason, man viewed as a spiritual and physical being. His happiness and the full manifestation of all his force in reality, in time and space, require the restoration of his self-confidence and of the human power alienated in God, including love, might, reason, freedom: "The consciousness of God is the self-consciousness of man, cognition of God is the self-cognition of man." (Feuerbach 1966: 42). This critical approach is aimed not at any particular religion in history but to religion in general; Feuerbach does not oppose to it any personal, unique understanding of his own but eliminates it completely from the scene of culture and history, which he "sweeps clean" for man. And so that man might not become too lonely or abstract on this scene, he "personifies" man in the relationship of love for another, in the "I-You" relationship, which was much used in the following century by many philosophers. The core of religion is love, and since love is the alienated essence of man, in his real essence love also constitutes the core. Once enlightened by Feuerbach's anthropology, man will grow, will become strong and happy, and will no longer have need of religious alienation.

The critical attitude to the shortcomings of religion and to the social "evil" that contemporary religion has become motivates different responses in the authors of these two models: each creates his own alternative view as to the essence of religion - on one hand "the true" religion, and, on the other, the complete rejection of religion and God in the name of man. But the critique of "empirically given" religion made in both models is identical in many of its features and has lasting ethical value and normative worth even today. 
Nonka Bogomilova: Religion within Framework of Philosophical and...

\section{The moral essence of religion: Immanuel. Kant (1724 - 1804)}

In Kant's view rational nature is the generic principle, the source of the moral law, while human nature is the specific. Moral, not reason, is the essence of man; man's aim is to realize himself in the moral sense, not in happiness, knowledge, etc. Inasmuch as for Kant the moral application of reason is the basic legislative power, the source of the supreme, it follows that God and religion have no autonomous importance or superior status, but are included, involved in this function of reason (Gadamer 1999). They are "supplementary impulses" for man's fulfilling his moral obligations, as, owing to his "moral incredulity", man is not usually directed by the principles underlying his deeds. Here religion and God are treated functionally, in the perspective of their morally relevant dimensions. Kant himself, in constructing this both transcendent and immanent rational instance, does not ground in any other way - intellectual or through faith the need and reality of God and religion, but sets them in terms of their functional purpose: the only true and necessary religion is moral religion. The latter is a religion that motivates and sanctifies human moral obligations, making of them divine commands, and thus facilitating the performance of these obligations for people who are inclined to give in to various temptations (Kant 1997: 9-12).

As in the other philosophical approaches to religion reviewed here, Kant's is highly critical of actually existing religion, the "religion of the cult", which not only does not help but, indeed, hampers the moral self-fulfillment of man. Moral religion as Kant understands it overcomes likewise the division and mutual clash between the various historical religions: all of them become expressions of, and mediators between, the common features of the human moral essence. Evil in man does not stem from God and is not compensated for by Him, but is the product of man himself, of the abuse of man's free choice.

In this way Kant grounds a theoretical and practical model that was to become rather popular among philosophers (especially in the following century): the religious is subordinated to various human projects, ventures, dimensions, including political, ideological, and nationalistic. But in most of these "uses" of religion, the divisive and conflictual aspects of religion come into play, for religious practices are separate group and community practices. This is how yet another characteristic approach to the knowledge of religion is formed: its divided, ambivalent interpretation according to different criteria, such as individual and society (J.-J.Rousseau, H.Bergson, S.Kierkegaard), essence and existence (K.Marx, S. Freud), authoritarianism and humanism (E.Fromm), etc. Kantian 
moral religion, although it does not cover the whole complex and multi-faceted phenomenon of religion, emphasizes one of its essential features, pointed out likewise by Hegel and Schleiermacher: man is part of a large moral community of mankind, of all people, and as such has a duty to them, a practical imperative, Kant's "ought to", which Hegel resolves theoretically through the principle of the identity of the notion and being.

Max Weber's analysis of the interweaving of religious treads in the spirit of capitalism (as well as that of the early E. Fromm) refer to this "functional" approach to religion, but in the perspective of group practices as participating in the formation of the ethos of a type of person who belongs to a concrete society and culture. M.Weber (1864 - 1920) describes self-reflectively and in detail the specific methodological viewpoint and cognitive task that determine his interpretation of the religious phenomenon, i.e. its function as an impulse to practical action and as a factor for the formation of the type of man typical for the spirit of capitalism. Although the conceptions of the two thinkers differ as regards the role of religion in the social process, their approaches are equally functional and involve a description of the conditions, limitations, and goals that make possible and effectuate the social process. This approach is especially important and instructive as concerns the present-day cases and analyses of the engagement of religion in various social situations: contacts and conflicts of a national, political, or cultural kind, the formation or breakdown of civilizations, etc. The analysis of the functional role of religion in all these cases requires a kind of methodological "hygiene", brilliantly demonstrated by Weber (Weber 1998). As for the modern condition of religion and its future Weber is firmly convinced: it is a relic of the past, and the analysis is, in fact, focused on that past.

\section{Religion as an attribute of im/perfect man and $\mathrm{im} /$ perfect society: K.Marx (1818 - 1883), S. Freud (1856 - 1939)}

After Feuerbach, or together with him, in the context of the specific moments of the cultural-historical process, man emancipated from God becomes the focus of attention of various philosophical schools and trends, and, depending on which "essential force" of man plays the decisive role according to various authors, they interpret religion in the context of that specific force. But another line of approach also developed, which we saw forcefully expressed by Feuerbach: the unequivocal definition of religion as an alienation of the human generic essence and the indicated necessity of abolishing, doing away with, this alienation, 
this distorted reflection, this "infantile fixation", etc. - K.Marx, S. Freud. According to the understanding of man as psychologically static (Freud), or as drawn into the historical dynamics of his world (social relations according to Marx), the disappearance of religion is related either to education and rearing or to the perfecting of the social relations themselves through a revolution and subsequent economic development (Janz 1998). The presence of religion in the past is taken to be a natural product of the respective state of human or social im/maturity, im/ perfection. The presence of religion in history is usually referred to the category of existence, of man's existence as characterizing past historical time. The variety of causes and conditions determining the decline and disappearance of religion depends on the interpretation of man's essence in each respective theory. In all the theories, religion is usually the opponent, the enemy, a mirrored counterpoint to the essence of man, which determines religion.

\section{Religion and the dichotomies of human nature: E.Fromm and P.Tillich}

Although Erich Fromm (1900-1980) rightfully belongs in the psychoanalytic movement, his divergence from Freud as regards the interpretation of human nature, the essence of man, involves a differing interpretation of the essence and future of religion. Fromm viewed religion as correlated to and functionally connected with (Fromm 2005: 63-64): 1). The two types of human attitudes - life affirming and life denying; 2). The two kinds of experience - $\mathbf{x}$-experience and non- $\mathrm{x}$-experience; 3 ). The two kinds of human character - humanistic and authoritarian

In his interpretation, these dichotomies of human nature are the decisive factor, so much so that they obviate the question of the nature of religion, which, in Fromm's perspective, is viewed as divided, ambivalent: authoritarian and humanistic; pertaining by some of its aspects to the $\mathrm{x}$-experience and by others to the non-x; affirming life or involved in man's "escape from freedom". Moreover, this opposition of characteristics is ascribed to all the great religions and is applied to their histories.

In postulating the existence of two types or aspects of religion, one of which plays a positive role for human self-assertion and the humanization of society, Fromm definitely moves away from the views of Freud, according to whom religion exists in a single form and indicates the immature, infantile stage at which the individual or culture find themselves; inasmuch as religion is an illusion and a collective neurosis, it is doomed to disappear as mankind attains maturity, grows 
up. In Fromm's view, on the contrary, it is not important whether religion is true or not, the important thing is the role it plays with respect to the human "task": humanistic religion proves to be a timely and promising means for the self-realization and self-affirmation of man. Together with this Fromm strongly criticizes the use of religion for the purposes of group narcissism, i.e. for nationalism and religious fundamentalism - this is a very relevant critical approach as regards the present-day usages of religion, which often involve clashes between the religions themselves. In fact, according to Fromm's perspective, religion may be drawn into both authoritarian and humanistic practices, depending on the type of society and type of human character that lies at its core (Fromm).

Although he defines religion in a universalistic perspective as a "depth" dimension of culture, as commitment of the whole human being, including man's thought, feeling, action, to the unconditional and infinite, which is the very essence of religion, Paul Tillich (1886-1965) also places religion in the context of the human existential situation, which he characterizes as anxiety, as fear of the finite, and sees religion as offering an escape from this anxiety into the infinite, the unconditional, the autonomous being, which characterize religion and the divine. The theology of Paul Tillich was innovative and vibrant, in contrast with the Protestantism of his time, which was linked with nationalism and state power. These qualities are manifest in Tillich's striving to "heal" faith, to substitute live, viable speech and symbols for the deadened ones. Unlike other philosophers and theologians, who accepted the interpenetration of essence and existence in man and thereby put a positive, optimistic stamp upon the personal and social transformations of humankind, Tillich viewed this connection in a reconciliatory perspective. Human nature, in his view, is initially and irrevocably divided between the latent innocence of man's essence and the universal alienation of his existence, which is marked by the metaphysical guilt of finitude and the personal guilt of sin, desire, idolatry. The fact that creation and the fall coincide makes sin not only a matter of personal responsibility but of ontological necessity.

The split of human existence into essence and existence, into potential and fulfillment, the definition of existence as "falling away", as anxiety, define Tillich's interpretation of religion. The latter is "... that place where life accepts him who has triumphed over the ambivalence of the living, divine Spirit." (Tillich 2000 - 2: 357). Religion relates to the functions of the spiritual life of man and is a sphere where the search for a New Being is constantly renewed despite the cleavage dividing essence and existence. Inasmuch as, for Tillich, anxiety and alienation are not historical but ontological categories, taken as eternal, substantial characteristics of human exis- 
tence, they are not surmountable through education and enlightenment (as Feuerbach takes it to be), but only through "courageous acceptance".

Tillich also emphasizes the ambivalent approach to religion resulting from the contradiction between essence and existence, the division of human being; hence religion comports, along with the holy, also the demonic, it submits to the law of ambiguity. The display of this demonic aspect is idolatry, which consists in absolutizing of the symbols of the holy; Tillich often warns against absolutizing and against taking the symbols of the holy in the literal sense; instead one should seek the deep essence manifest in all religions: this is the path that he indicates to achieving the peaceful coexistence of religions: "The opposition between religions is not an opposition of the forms of faith but an opposition of the means for expressing the ultimate concern." (Tillich 1995: 176).

But idolatry is still faith, and the demonic holy is still holy: this is precisely the ambivalence of faith according to Tillich. Here he entirely differs from Schleiermacher, who recognizes the existence of a single, intimate, and lofty faith and religion as a form of perception of the universe. Tillich's view also differs from those of the other thinkers presented above, for he encompasses the positive and negative characteristics of religion under the integral concept of "religion", and does not attribute them to its different bearers, forms of manifestation, etc. Thus religion comes to correspond to, and be in harmony with, the ambiguity, the inner contradiction, the "fallenness" of human nature.

\section{Religion within the framework of sociological approaches and definitions}

In the traditions of sociological research, religion is defined in the context of its analysis as part of the complex system of a concrete society, and as connected with that society's relations of power, property, production, and morality. The concrete historical type of religious notions, relations, and functional power in a society are deduced from the concrete interrelations between individual and groups in it, between its leader and masses, its type of productive activity (agriculture, hunting culture, urban or rural type), geographical features, proximity and contacts with other cultures, etc. The contemporary German sociologist of religion Horst Helle distinguishes three key epistemological paradigms, and definitions stemming thereof, in the scientific study of religion and specifically in the sociology of religion: those of Durkheim, of Simmel, and of Weber (Helle 1994: 58). Helle sees Weber's approach as being a synthesis of the epistemological paradigms of E. Durkheim and G.Simmel. Anthony Giddens links the development 
of Western sociology - and respectively the sociological study of religion as a component of the social whole - with late $19^{\text {th }}$ and early $20^{\text {th }}$ century integrative social trends, which sought to counteract the disintegrating effects of individualism, revolutionary trends, etc. (Giddens 1971: VII, IX, 199,201).

In the early 1990s, the authoritative British sociologist of religion Prof. James Beckford presented a general overview on the development of sociology of religion in its various dimensions and manifestations over a formidably long period the nearly half a century between 1945 and 1989. His analysis has been confirmed in many respects by a discussion embracing a slightly longer period, and dealing with the formation and development of the conceptual perspective of Social Compass, the journal of one of the highly reputed associations in its field, the International Society for the Sociology of Religion (ISSR), whose trends the journal has reflected for many years (Mejido 2004; Houtart 2004; Bastenier 2004).

Although Beckford's analysis is focused on the sociology of religion of this period (more detailed information: Bogomilova 2017), inasmuch as the various fields of the study of religion are not isolated from one another, his discussion also touches upon other disciplines, such as history, theology, philosophy, ethnology, psychology.

The known British sociologist J. Beckford characterizes the period from the late 19 th century to the early 20 th century as the "golden age" of sociology of religion, for that was when the basic epistemological paradigms were established, with which sociologists of religion have continued to work during the whole 20th century and until now. This refers to the theories of Max Weber, Georg Simmel, Ernst Troeltsch, Emile Durkheim, etc. (Beckford 1990: 46). It is not accidental that the great sociologists of this "golden age", in addition to their other interests, produced major works on sociology of religion as a general subject (Allardt 1989: 65).

The concept of "religion", central to all sciences engaged in understanding the religious phenomenon, continues to be a subject of debate, Beckford notes. He finds these debates are also going on in other sciences of religion, such as anthropology of religion, history of religion and ethnology. In support of this view, we may refer to the article by the French author Yves Lambert (published one year after Beckford's article in the same journal) 'La 'Tour de Babel' des définitions de la religion" (Lambert 1991).

As a generalization of the theoretical perspectives in sociology of religion from 1945 to 1989, Beckford identifies the following orientations, tendencies and turns of its development during this period: In the immediate post-war period, religious sociology continued to be a fruitful form of interpretation of religion. In 
the following decades, there was a stricter specialization, and division of labour was made between theology and the sciences of religion. The strong influence of Talcott Parsons' normative functionalism was evident; in the sphere of sociology of religion, this perspective drew the attention of researchers to the functions of religion in modern societies as related to its connection with economic development, democratic policy, cultural pluralism, and the "adaptive" personality. The influence of Parsons' theory is manifest in the strong growth of studies on civic religion, denominations, the Protestant ethic and economic development, the institutionalization of sects, and religious pluralism (Beckford 1990: 55).

To this, we should add the new aspects of religious studies stimulated by newly arising social processes and forms, such as consumer society (Spasova 2019), immigrants, ethnocentrism, ecology (Nikolova 2019), and developing actively also in the Balkans (Bogomilova 2020). In the next two decades and at present, this circle of problems has continued to be among those most actively researched and written about in a large number of publications. It suffices to examine the catalogues of the large international publishing houses Brill, Ashgate, Edwin Mellen Press, Oxford University Press, and the contents of journals of sociology and religious studies (Science of Religion 2012: 37-132).

Later in his analysis, Beckford considers in a critical perspective certain tendencies towards reduction and operationalization of the concept of "religion" for the purposes of questionnaire social surveys on religious experience. The target of his criticism is sociology's inclination to universalize the measurement approach, its confidence that the parameters of the religious phenomenon are measurable. The reduction of religion to verbal testimonies, conduct and beliefs of individuals enables capturing and recording only "privatized" religion filtered through personal identity, concepts and relations. It ignores the cultural and social influence of religion as a collective phenomenon, as Beckford concludes (Beckford 1990: 52). In support of his observation, we can add that a number of surveys at European, regional and national level have acknowledged that when personal religiosity is "measured" in a country and culture, much lower values are obtained for it than for religiosity seen as "affiliation" to a religious tradition, ethnic group, cultural identity, as measured by national censuses and statistics. The clear distinction between these two aspects, and the creation of theoretical and empirical instruments for capturing them in unity, would increase the reliability and operational capacity of social studies, whose deficits are the target of the author's critical remarks.

Beckford sees a trend of distancing away from this individualizing religion in sociology's new heightened interest in phenomena like implicit religion, popu- 
lar and unofficial forms of religion, about which a growing number of authors are writing today. According to him, this trend is a kind of revision of the church-oriented sociology of religion of the 1970 s, and can be seen as an attempt to highlight the collective forms of practicing and experiencing religion, although the trend of privatized conceptualization of religion is still also prevalent.

In his further analysis of the basic concepts and themes of sociology of religion in the period under discussion, Beckford gives a positive evaluation of the sociological focus on the complex relationships between religion and politics, the Church and the state. He finds that, beginning from the 1960s, sociologists showed increased interest in these topics in the context of the problems of modernization, civil rights, the ecological crisis, and poverty. He registers that, in principle, the sociology of religion had shown sensitivity towards the strong connection between religions and power (Beckford 1990: 52).

Later Albert Bastenier would draw a general conclusion, that the sociology of religion is at a turning point of its history and of its theoretical evolution (Bastenier 2004: 7).

In his article of 1990, J.Beckford drew the general conclusion, valid today as well, that the social functions of religion, with which sociologists were occupied after 1945, had decreased, but the social importance of religion, in a new form, had perhaps increased. This new form requires new conceptualization.

In the last 20-30 years, as a result of the growth of individualism as a principle informing all spheres of postmodern culture, certain categories have come to the fore in the methodology of religious studies, which highlight individual "religious experience" (Versteeg and Roeland 2012); thus, subjectivity becomes central to the understanding of the divine (Lee 2008). This trend does not eliminate the validity and the fruitfulness of the sociological approach. Pointing out the role of the group and the authority in religious experience, Versteeg and Roeland state that "Subjectivization in religion is not the spiritual equivalent of the modern autonomous subject who controls his world through experience and self- discovery" (Versteeg and Roeland 2012, Conclusion).

\section{The Cognitive Science of Religion: beyond philosophical and sociological approaches?}

That the concept of religion is still a topic of continuing debate, as it was more than 30 years ago, when Beckford published his comprehensive article, is confirmed by the intense discussions taking place around the so-called Cogni- 
tive science of religion (Shunke 2015; Green 2015; Wilkins 2015). Many authors have acknowledged that the scientific study of religion has undergone dramatic transformations in recent decades, related to the fermentation of ideas in psychology and evolutionary biology (Pearson and Shunke 2015: 47). This new approach is designated as the cognitive science of religion (CSR).

The cognitive science of religion, one of the rapidly developing branches of the so-called new sciences of religion in the last ten years, is related to naturalizing approaches to its subject, and is based on the developments and achievements of psychology and evolutionary biology. One of the recent issues of the journal Sophia, published by Springer, presents several theses on this topic, discussed by specialists in philosophy, cognitive science, psychology, and religious studies (Shunke 2015: 45). This discussion (Shunke 2015; Green 2015; Wilkins 2015 ) "shows the diversity of approaches, that can be grouped under term of naturalizing religion, giving a sense of key issues in this still developing and emerging fields." (Shunke 2015: 45).

The authors reduce the two camps' dispute on the explanation of religion to two contrasted stances: the camp of the "sui generis" approach concedes that religion is a unique phenomenon, the nature of which may be understood only by means of unique methods in harmony with that nature. The use of any other type of methods (historical, psychological, sociological) misses the specificity of religion (Pearson and Shunke 2015: 50). Thus, the aim of the "sui generis" approaches is protectionist with regard to the specificity of religion: the aim is to safeguard it from reductionist strategies. Adopting these approaches, researchers become protectors of religion and of the sacred, safeguarding it from approaches that are non-relevant to the nature of the subject; in other words, they devise protectionist strategies for religion (Pearson and Shunke 2015: 50).

In the opposite camp are the reductionists, who assert they are emancipating religion from protectionist strategies that take into consideration the viewpoint of believers and that tolerate crypto-theological views on the issue, thereby assuming a specific research commitment to religion (Pearson and Shunke 2015: 51).

Here, reductionism is seen as eliminating the specifically religious elements from the researcher's perspective, while the "sui generis" approach is considered to involve a theological, pro-religious commitment. The latter group of scholars considers reductionist approaches to represent a threat to religion, its infiltration by non-religious elements. The naturalists, for their part, believe that the risk to understanding religion lies in the restrictive approach to religious studies and their infiltration by "interested" approaches that comply with religion (Pearson and Shunke 2015: 52). 


\section{Conclusion}

Regardless of the change of concepts describing it, and the new, innovative concepts used to interpret the approaches that are alternative to it, ultimately this CSR approach reproduces a dilemma with a long cultural and intellectual history overviewed in our study: that between scientific, rational knowledge of religion, pursued also by philosophical and sociological approaches, and the "understanding", "experiencing" of religion, the insight into its unique psychological and metaphysical core, accessible only to those with religious experience. This opposition mirrors the two value-based existential strategies: between the longing for religion and a life lived without illusion.

\section{References}

Allardt, E. 1989. Commentary on James Beckford's and Emile Poulat's Papers on the Predicament of the Sociology of Religion. Social Compass 37 (1): 65-69.

Bastenier, A. 2004. Introduction. Social Compass 51(1): 5-7.

Beckford, J. 1990. The Sociology of Religion 1945-1989. Social Compass, 37 (1), 45-64. Bogomilova, N. 2010. Religiyata i choveshkata sashtnost. Klasicheski idei [Religion and Human Essence: Classical Ideas]. Sofia: Academic Publishing House "Prof. Marin Drinov".

Bogomilova, N. 2017. The Sociology of Religion from the Second Half of $20^{\text {th }}$ Century: A Western Perspective (on J.Beckford's analysis) In Matic, Z., Blagojevic, M. (eds.). Religion in Contemporary Society. Thematic conference proceedings of international significance held in Srebrno jezero (Veliko Gradiste), May 19 and 20 of 2017. Belgrade: Institute of Social Sciences, pp. 229-240.

Bogomilova, N. 2020. Religiyata v teoretichnoto pole na savremennite balkanski izsledovateli (kontekstat na razpadaneto na bivsha Yugoslaviya) [Religion Within the Theoretical Field of Contemporary Balkan Scholars ( In the Context of the Collapse of the Former Yugoslavia)] Slavia Meridionalis 20, Article No.: 2154 DOI: https://doi.org/10.11649/sm.2154

file://C:/Users/Nonka/AppData/Local/Temp/2154-15192-1-PB.pdf

Feuerbach, L. 1966. Sashtnost na hristiyanstvoto [The Essence of Christianity]. In: Feuerbach, L. Izbrani proizvedeniya [Selected works]. Sofia: BKP, vol. 2.

Fromm, E. 2005. Shte badete kato bogove (Radikalno talkuvane na Stariya zavet i negovata traditsiya) [You Shall Be As Gods: A Radical Interpretation of the Old Testament and Its Tradition]. Sofia: Zaharii Stoyanov.

Gabellieri, E. 2004. Philosophie de la religion et "philosophie religieuse" (S. Weil). In Philippe Capelle et Jean Greisch (éd.). Raison philosophique et christianisme à l'aube de IIIe millénaire. Paris: CERF, 289-294.

Gadamer, H.-G. 1999. Kant and the Question of God. In: Gadamer, H-G. Hermeneutics, Religion, and Ethics. New Haven and London: Yale University Press, 1-17. 
Giddens, A.1971. Capitalism and modern social theory. Cambridge: Cambridge University Press.

Green, A. 2015. The Mindreading Debate and the Cognitive Science of Religion, Sophia $54 / 1,61-75$.

Greisch, J. 2004. Qu'appelle-t-on "s'orienter dans la pensée"? Une meditation métaphilosophique. In: Philippe Capelle et Jean Greisch (éd.). Raison philosophique et christianisme à l'aube de IIIe millénaire. Paris: CERF, 27-52.

Hegel, G.W.F. 1996. Razumat v istoriyata [Reason in History]. Sofia: LIK.

Hegel, G.W.F. 2004. Filosofska propedevtika [Philosophical Propaedeutic]. Sofia: Europe.

Helle, H. 1994. Epistemologicheski paradigmi v nauchnoto izsledvane na relgiyata [Epistemological Paradigms in the Scientific Study of Religion]. Filosofski alternativi [Philosophical Alternatives] № 5, 58-60.

Houtart, F.2004. Les 50 ans de Social Compass: authobiographie d'une revue qui s'est trompée de nom. Social compass 51 (1): 9-22.

Janz, D. 1998. World Christianity and Marxism. New York, Oxford: Oxford University Press.

Kant, I. 1997. Religiyata $v$ granitsite na samiya razum [Religion Within the Limits of Reason Alone]. Sofia: Otvoreno obshtestvo.

Lambert, I. 1991. La "Tour de Babel" des définitions de la religion. Social Compass 38(1), 73-85.

Lee, Raymond. 2008. "La fin de la Religion? Réenchantement et déplacement du sacré". Social Compass 55(1), 66-83.

Mejido, M. 2004. On the Genesis and Transformations of Social Compass. Social Compass 51 (1): 23-44.

Nikolova, A. 2019. Religious Aspects of Deep Ecology. In Bogomilova, N. (Ed.) Religion and Social Ecology (Philosophical-Anthropological Problems of Un/SustainableDevelopment) Sofia: OMDA.bg

http://www.omda.bg/public/biblioteka/e-books/SbornikReligijaEcologija2019.pdf

Pearson, Ch., M. Shunke. 2015. Reduction, Explanation and the New Science of Religion. Sophia 54(1), 47-60.

Schunke, M.P.2015. Introduction to Half Special Issue on Naturalizing religion. Sophia 54 (1): 45.

Science of Religion. 2012. 37 (1-2).

Raynova, I. 1997. Razgranichenieto mezhdu filosofski i religiozen diskurs v tvorchestvoto na Pol Rikyor [The Distinction Between Philosophical and Religious Discourse in the Works of Paul Ricoeur]. Filosofski Alternativi [Philosophical Alternatives] № 4, 16-29.

Sazonova, L.2018. Evropeiska identichnost: diskursivno ili ekzistentzialno? [The European Identity: Discoursive or Existential?]. Varna: EI Liternet.

Schleiermacher, F. 1994. Za Religiyata [For Religion]. Sofia: LIK.

Spasova, M. 2019. The Religious Archaic: Modern transformations (Bulgarian context). In Bogomilova, N. (Ed.) Religion and Social Ecology(Philosophical-Anthropological Problems of Un/SustainableDevelopment) Sofia: OMDA.bg 
http://www.omda.bg/public/biblioteka/e-books/SbornikReligijaEcologija2019.pdf

Tillich, P.1995. Dinamika veri [Dynamics of Faith]. In: Tillich, P. Izbrannoe. Teologiya kulyturi [Selected works. Theology of Culture]. Moscow: Yurist, 132-215.

Tillich, P. 2000. Sistematicheskaya teologiya [Systematic Theology]. Moscow: Universitetskaya kniga, vol. 2.

Weber, M. 1998. Kriticheski izsledvaniya varhu logikata na naukite za kulturata [Critical Studies on the Logic of the Cultural Sciences]. In: Weber, M. Meaning and Value. An Anthology. K. Koev (ed.). Sofia: K\&H, 85-153.

Versteeg, P. and J. Roeland. 2012. Contemporary Spirituality and the Making of Religious Experience: Studying the Social in the Individualized Religiosity. Fieldwork in Religion 6(2), 120-133. https://www.researchgate.net/publication/273082766

Wilkins, J.S. 2015. Gods Above: Naturalizing Religion in Terms of our Shared Ape Social Dominance Behaviour. Sophia 54 (1): 77-92.

\section{References in Cyrillic}

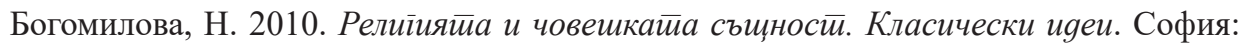
Академично издателство „Проф. Марин Дринов”.

Вебер, М. 1998. Критически изследвания върху логиката на науките за културата. В: Вебер, М. Смисъл и иченности. Анйолойия. К.Коев (съст.). София: КХ, 85-153.

Кант, И. 1997. Релиїияйа в іраницииее на самия разум. София: Отворено общество.

Райнова, И. 1997. Разграничението между философски и религиозен дискурс в творчеството на Пол Рикьор. Философски алиеернайиви №. 4, 16-29.

Тиллих, П. 1995. Динамика веры. В: Тиллих, П. Избранное. Теолоїия кульйуры. Москва: Юрист, 132-215.

Тиллих, П. 2000. Систиемайическая тееолойия. Москва: Университетская книга, т. 2.

Фойербах, Л. 1966. Същцносй на християянстивойо. В: Фойербах, Л. Избрани ирроизвеgения. София: Партиздат, т. 2.

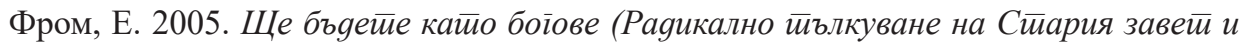

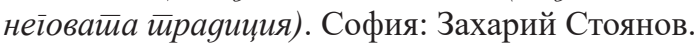

Хегел, Г.В.Ф. 1996. Разумъй в истиорияйа. София: ЛИК.

Хегел, Г. В.Ф. 2004. Философска йройеgевйика. София: Европа.

Хелле, Х. 1994. Епистемологически парадигми в научното изследване на религията. Философски алитернайиви № 5, 58-60.

Шлайермахер, Ф.1994. За релиіияйа. Речи към образованийе нейни оитрицайели. София: ЛИК. 


\title{
Nonka Bogomilova
}

Professor, Dr.Sc.

Bulgarian Academy of Sciences

nonka_bogomilova@mail.bg

\section{RELIGIJA U OKVIRU FILOZOFSKOG I SOCIOLOŠKOG PRISTUPA}

\begin{abstract}
Rezime
U radu je dat pregled nekih specifičnosti filozofskog $i$ sociološkog pristupa religiji. Među odabranim filozofskim epistemološkim modelima opisani su: religija kao universum (F.Schleiermacher, G.V.F. Hegel); antropocentrični pristup; religija protumačena kao moralni fenomen (I.Kant); religija u okviru dihotomija ljudske prirode (E.Fromm, P.Tillich). Autor predstavlja i komentariše nekoliko aspekata J.Beckfordove analize problema i trendova u sociologiji religije. Istaknuti su najnoviji događaji u kognitivnoj nauci o religiji (DOP).
\end{abstract}

Ključne reči: znanje o religiji, filozofija religije, sociologija religije, problemi i teorije, epistemološki modeli, kognitivna nauka o religiji. 